\title{
The Efficacy of Posterior Turbinoplasty in Combination with Tonsillectomy and Adenoidectomy in Pediatric Sleep Disordered Breathing Patients
}

\author{
Jae Hoon Bae, Jang Su Lee, and Nam Guk Kim \\ Department of Otolayngology-Head and Neck Surgery, Kwangju Hospital of Christian, Gwangju, Korea
}

\author{
수면호흡장애 소아에서 편도 및 아데노이드 절제술과 비갑개 후방축소술 \\ 동반 시행 시 효용성에 대한 고찰
}

배재훈 · 이장수 · 김남국

광주기독병원 이비인후과

\author{
Received July 15, 2019 \\ Revised November 15, 2019 \\ Accepted November 19, 2019 \\ Address for correspondence \\ Nam Guk Kim, MD \\ Department of Otolayngology- \\ Head and Neck Surgery, \\ Kwangju Hospital of Christian, \\ 37 Yangnim-ro, Nam-gu, \\ Gwangju 61661, Korea \\ Tel $+82-62-650-5095$ \\ Fax $+82-62-650-5090$ \\ E-mail cielo3797@naver.com
}

Background and Objectives Tonsillectomy and adenoidectomy (T\&A) are effective for the treatment of pediatric sleep disorder breathing. However, in some pediatric patients, there remain unresolved snoring and mouth breathing problems after the operation. This study is aimed at evaluating the efficacy of coblation of hypertrophic posterior turbinate in combination with tonsillectomy and adenoidectomy.

Subjects and Method We analyzed data from 50 children aged between 5 to 13 years old who were scheduled to undergo T\&A operation from June 2018 to December in 2018. We randomly divided them into two groups. The first group consisted of 25 patients who were scheduled to perform only tonsillectomy and adenoidectomy. The second group was 21 patients who were scheduled to perform posterior turbinoplasty in combination with tonsillectomy and adenoidectomy. We evaluated preoperative and postoperative polysomnogram [Apnea-Hypopnea Index (AHI), O2 saturation], acoustic rhinometry (minimal cross section area, nasal volume), and Korean Obstructive Sleep Apnea-18 Survey (KOSA-18) score.

Results After additional turbinoplasty (coblation of hypertrophic posterior turbinate), the rate of snoring and mouth breathing remaining was decreased. There were significant improvements in AHI, oxygen saturation, Visual Analog Scale and Epworth Sleepiness Scale in two groups. Symptoms (snoring and mouth breath) remaining postoperatively was much more decreased in the posterior turbinoplasty combined with T\&A group than in the single T\&A group in terms of KOSA-18.

Conclusion When it comes to pediatric sleep disorder breathing surgery, nasal cavity evaluation is an important factor for patient's postoperative satisfaction for sleeping and snoring. For pediatric sleep disorder breathing patients with hypertrophic posterior turbinate, who are scheduled to do tonsillectomy and adenoidectomy, an additional coblation of posterior turbinate should be considered. Korean J Otorhinolaryngol-Head Neck Surg 2020;63(5):216-22

Key Words Posterior turbinate hypertrophy · Sleep disordered breathing · Tonsillectomy.
서 론

편도 및 아데노이드 비대에 의한 만성 상기도 폐쇄는 소아
에서 수면호흡장애를 일으키는 가장 흔한 원인이며, 이러한 소아는 코골이, 무호흡, 구강 호흡 등의 증상뿐만 아니라 성 장장애, 야뇨증, 주의력결핍, 과잉행동장애 등이 잘 생긴다고

This is an Open Access article distributed under the terms of the Creative Commons Attribution Non-Commercial License (https://creativecommons.org/licenses/by-nc/4.0) which permits unrestricted non-commercial use, distribution, and reproduction in any medium, provided the original work is properly cited. 
알려져 있다. ${ }^{1-3)}$ 또한 수면무호흡증후군은 소아의 1 3\%에서 나타나지만, 수면호흡장애는 소아의 $11 \%$ 정도까지 나타나는 것으로 보고되고 있다.")

수면호흡장애가 있는 소아에 있어서 효과적인 수술적 치 료로 편도 및 아데노이드 절제술을 일반적으로 시행하고 있 다. ${ }^{5,6)}$ 편도 및 아데노이드 절제술은 성공률이 매우 높은 편 이나 종종 술 후에도 코골이, 구강호흡, 수면 저호흡 및 무호 흡이 남아 여전히 수면의 질이 떨어지고 나아가 삶의 질 저 하로 이어져 결국은 수술에 대한 만족도가 떨어지는 경우를 때때로 접하게 된다. 이런 상황을 겪는 환아들을 대상으로 신체검진을 하게 되면 많은 경우에서 하비갑개 비대증 같은 비폐색 및 비강기도저항이 있음을 알게 된다.

Ellis 등 ${ }^{8)}$ 은 비강기도저항 및 비폐색은 전체 기도저항의 약 절반을 차지하는 중요한 기능적 구조이고 이는 코골이 및 폐쇄성수면무호흡증 발생에 있어서 중요한 역할을 한다는 것 이 알려져 있을 뿐 아니라 이러한 증상을 동반한 환자에서 코수술이 증상 호전에 효과가 있다고 보고하였다.

본 연구진은 비중격 만곡증이나 하비갑개 비대증 등과는 달리 비강패킹이 필요하지 않고, 수술시간, 수술부위, 관련 처치가 짧고 간결하게 진행할 수 있다는 점에서 비갑개 후 방 비대증이 있는 경우만을 연구대상으로 하였다.

이를 통해 편도 및 아데노이드 절제술 시행 환자로 술전 검사에서 비갑개 후방비대증이 확인되어 하비갑개 후방축소 술을 동시 시행하는 경우 술 후 잔존하는 코골이 및 구강호 흡 등의 증상 감소를 포함하여 전반적인 수술 후 삶의 질 개 선에 미치는 영향을 알아보고자 하였다.

\section{대상 및 방법}

\section{하비갑개 후방 비후의 정의}

본 연구에서는 비내시경(sinus endoscopy)으로 반복 관찰 시, 비강의 $3 / 4$ 이상 공간을 차지할 때를 비갑개 후방 비대 (posterior turbinate hypertrophy)가 있는 상태로 정의하였 다. 이 경우에 한해 coblation을 통한 비갑개 후방절제술이 필요하다고 보았으며, coblation 후 비내시경을 통해 비갑개 후방 축소(hypertrophic posterior turbinate shrinkage) 정 도를 확인하였다. 궁극적으로 coblation 후 비강의 2/4 1/4 수준으로 축소하는 것을 목표로 하였다.

\section{대 상}

2018년 6월부터 12월까지 본원 이비인후과에서 수면호흡장 애를 해결하기 위해 편도 및 아데노이드 수술을 계획 중인 5 13세 사이의 소아 중, 수술 전 비내시경 평가에서 비갑개 후
방비대가 확인된 50명의 환아를 대상으로 하였다.

연구 참여자 선정에 있어 Body Mass Index 30 이상의 고 도비만, 비중격 만곡증, 심한 비갑개 전방비대, 알레르기 비 염이 있는 경우, 법적 보호자가 동거하지 않는 경우 등의 배 제기준에 포함된 경우는 제외하였다. 50 명의 환아 중 25 명을 선정 후 비갑개 후방비대 축소술(coblation)을 권유하였고 법적 보호자의 동의를 얻은 21 명이 연구에 참여하였다. 이 과정에서 환자 분류는 임의적으로 시행되었다. 실험군 대상 자에 대해 비갑개 후방 축소술시 발생 가능한 출혈, 통증, 비 강 내 불편감 등 합병증 가능성에 대해 설명하였다.

본 연구는 광주기독병원 기관생명윤리위원회의 검토 및 승인을 받았다(KCH-M-2018-03-007).

\section{연구 방법}

본 연구 참여자 46 명 중 대조군으로 선정된 25명은 기존 의 예정된 편도 및 아데노이드 수술을 받고 이후 비충혈 개 선제를 복용하기로 하였다. 한편, 실험군으로 분류된 21명의 환아에 대해서는 편도 및 아데노이드 수술시 비갑개 후방비 대부위에 대해 coblation을 추가 시행하고 술 후 마찬가지로 비충혈 개선제를 복용하도록 하였다.

수술 전후 수면다원검사를 통해 수면무호흡과 저호흡 및 산소포화도 수치를 기본적으로 비교하였고, 음향비강 통기 도 검사를 통해 술전 및 술후 비강의 공간적 변화를 평가 하였다. 또한, 수면호흡장애, 잔존 코골이, 구강호흡 등을 포함하는 전반적 삶의 질 변화에 대한 평가를 위해 법적 보호자의 설문을 통한 평가가 포함된 Korean Obstructive Sleep Apnea-18(KOSA-18)을 활용하였다.

\section{수술 방법}

연구에 참여한 모든 환아는 수술에서 로우즈위(Rose position)로 배와위를 취한 후 수술대 위로 머리와 목을 신전시켰 다. 전신마취를 진행한 후 coblator를 이용해 편도 및 아데노이 드 절제술을 시행하였다. 수술 시 편도 및 아데노이드 절제술 시에는 Coblator(EVac 70; Arthrocare corporation, Sunnyvale, $\mathrm{CA}, \mathrm{USA})$ 를, 비갑개 후방 축소술 시에는 Coblator(ReFlex U1tra 45; Arthrocare corporation)를 사용하였다(Fig. 1).

비갑개 후방 비대 축소술을 동시 수술하는 환아들의 경우 수술 중 비내시경을 통해 비대부위를 확인하고 수술 자세 변 화 없이 비갑개 후방의 비후 부위를 coblation하였다. Coblator를 이용해 비갑개 후방비대의 축소와 지혈을 동시에 진 행 후 보스민 및 1:100000 에피네프린 거즈 압박을 통해 추 가적 지혈을 시행하였다(Fig. 2). 

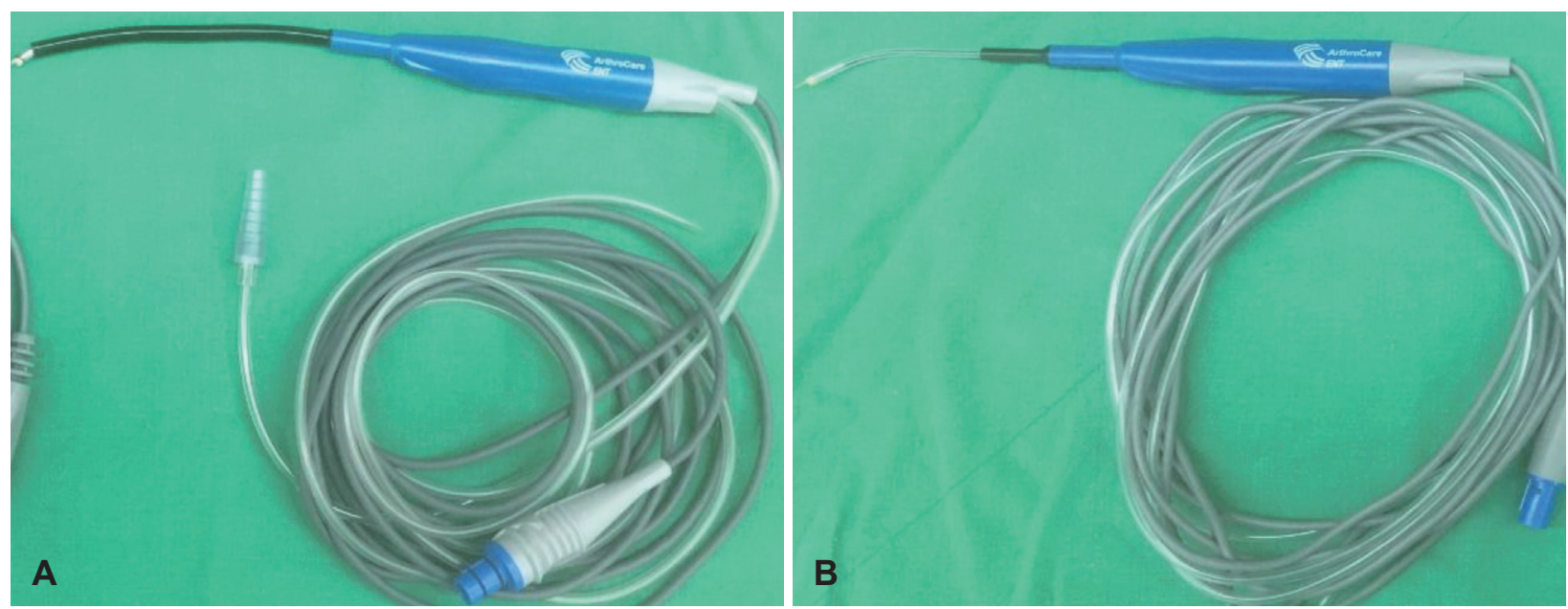

Fig. 1. Picture of coblaotor used in Tonsillectomy and Hypertrophic posterior turbinoplasty. Coblator ${ }^{\circledR}$ (EVac 70; Arthrocare corporation) used in Tonsilloadenoidectomy (A). Coblator ${ }^{\circledR}$ (ReFlex; Arthrocare corporation) used in resection of Hypertrophic posterior turbinoplasty (B).
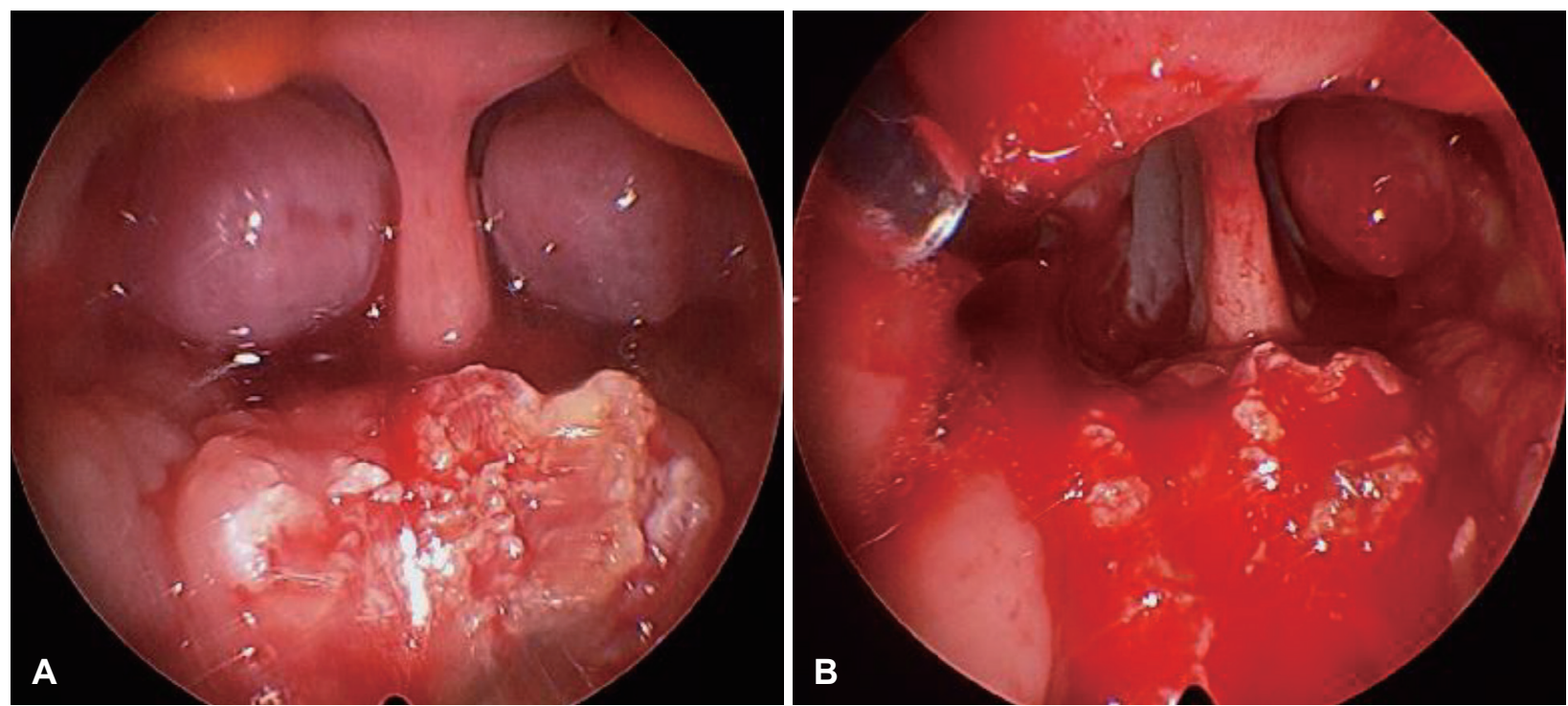

Fig. 2. Pictures of Hypertrophic posterior turbinate $(A)$ and its coblation (B). Hypertrophy of posterior turbinate $(A)$. Picture after coblation of hypertrophic posterior turbinate $(B)$.

\section{술 후 회복기간 등의 차이}

\section{수술 시간 및 회복기간}

수술 시간은 마취시간을 제외한 순수한 이비인후과적 수 술 시행에 소요되는 시간만을 측정하였다. 회복기간은 정상 식이 가능하며 비갑개 후방에 가피가 생기지 않는 기간으로 정의하고 퇴원 후 외래 추적관찰을 통해 확인하였다.

\section{코골이 및 구강호흡 등 잔존 증상에 대한 평가}

수면상태시 잔존증상에 대한 평가는 앙와위 상태에서 확 인하도록 하였다. 코골이 및 구강호흡 등 잔존 증상의 유무
에 대한 평가 설문을 포함하여 수술전후에 폐쇄성수면무호 흡증으로 인한 삶의 질 변화에 대해 평가하였다. 평가방법으 로는 환자군의 연령이 낮음을 고려하여 KOSA-18 설문을 이 용하였다. ${ }^{9)} \mathrm{KOSA}-18$ 은 Obstructive Sleep Apnea-18 (OSA-18)을 한글 번역한 설문으로 수면상태, 신체적 증상, 정서적 증상, 낮시간의 생활, 보호자 상태 등의 카테고리에서 세부사항에 대해 1 7점까지 점수로 평가하며 총점은 18 126점까지 평가한다. ${ }^{910)}$ 본 연구진은 KOSA-18 점수의 개선을 통해 수술에 대한 만족도를 평가하였다. 


\section{수면다원검사}

연구대상 환아들은 수술 전후로 수면다원검사를 시행하 였으며, 무호흡-저호흡지수(Apnea-Hypopnea Index, AHI) 및 산소포화도 변화를 비교 분석하였다.

본 연구에서 수면다원검사는 Embla N7000(Natus Medical Inc., San Carlos, CA, USA)을 이용하여 오후 11시부터 익일 오전 7시 사이에 시행하였다. 또한, 수술 후 증상의 경감 을 평가하기 위해 $\mathrm{AHI}$ 를 이용하였다. 환아들은 수술 전 1차 수면다원검사를 시행하였고, 수술 후 약 8주 시점에 2차 수 면다원검사를 시행하여 수술 전과 수술 후의 $\mathrm{AHI}$ 와 평균 산소포화도를 비교하였다.

\section{음향비강통기도검사}

연구대상 환아들에 대해 수술 전후로 외래에서 음향비강 통기도 검사를 진행하였다. 대조군 및 실험군 모두에서 수술 전 비충혈 개선제를 복용한 상태에서 검사를 시행하였고, 수 술 후 8 주 시점에 비충혈 개선제를 지속 복용하는 상태에서 검사를 진행하였다.

\section{통계 분석}

모든 통계분석은 SPSS 17.0(SPSS Inc., Chicago, IL, USA)을 이용하였고 Paired t-test를 이용하여 수면다원검사 $\mathrm{AHI}$ 값, 산소포화도, 음향비강통기도검사[minimal cross section area(MCA), nasal volume], KOSA-18 등의 수술 전 후 변화를 분석하였다.

한편 편도 및 아데노이드 절제술만을 시행한 대조군과 편 도 및 아데노이드 절제술과 함께 비갑개 후방 축소술을 시행 한 실험군의 수술 후 군간의 효과성 비교에 있어서는 $\mathrm{Stu}^{-}$ dent's t-test를 이용하여 평가하였다.

\section{결 과}

\section{수술 시간 및 회복기간}

수술 소요 시간에 있어서 편도 및 아데노이드 절제술의 경 우 평균 $22.3 \pm 3.39$ 분 소요되었고 후방 비갑개 축소술을 추 가 시행하는 경우 평균 $30.1 \pm 3.17$ 분 소요되어 약 7.8분 정도 가 추가로 소요되었다. 한편 회복기간에 있어서는 두 그룹 각 각 평균 $13.8 \pm 1.15$ 일, $14.3 \pm 1.20$ 일로 유의미한 차이가 없었 다. 또한 비갑개 후방 축소술 부위의 출혈이 있는 경우는 없 었다 $(p=0.132)$.

\section{수술 전후 수면다원검사 결과의 비교}

2018년 6월부터 12월 사이에 수술 받은 46명의 환아에서
수술 전후 평균 $\mathrm{AHI}$ 값 및 평균 산소포화도를 조사하였다.

대조군에서 수술 전 평균 $\mathrm{AHI}$ 값은 $7.85 \pm 1.90$ 이며, 수술 후 2 개월째 시행한 수면다원검사는 평균 $0.86 \pm 0.25$ 였다 $(p<0.05)$. 실험군에서 수술 전 평균 $\mathrm{AHI}$ 값은 $8.60 \pm 4.41$ 이며, 수술 후 2 개월째 시행한 수면다원검사는 평균 $0.86 \pm 0.27$ 이었 다 $(p<0.05)$.

산소포화도의 경우 대조군에서 수술 전 $88.6 \pm 1.6 \%$ 였으 며, 수술 후 2개월째 시행한 산소포화도는 평균 93.2 $\pm 1.3 \%$ 이었다 $(p<0.05)$. 실험군에서 수술 전 평균 산소포화도값은 $89.0 \pm 1.6 \%$ 이며, 수술 후 2 개월째 시행한 산소포화도는 평균 $93.3 \pm 1.2 \%$ 이었다 $(p<0.05)$.

편도 및 아데노이드 절제술을 통해 두군 모두 수면다원검 사 결과 $\mathrm{AHI}$ 값 및 산소포화도에서 통계적으로 유의미한 개 선이 있음을 확인하였다. 한편, 두 그룹 간 술 후 $\mathrm{AHI}$ 값 및 산소포화도 변화의 비교에서는 의미 있는 차이를 보이지는 않았다(Table 1).

\section{수술 전후 음향비강통기도검사 결과의 비교}

음향비강통기도 검사에서 편도 및 아데노이드 절제술만 시행한 환자군에서는 수술 전후 최소단면적(MCA)은 각각 $0.14 \pm 0.01,0.14 \pm 0.01 \mathrm{~cm}^{2}$ 로 측정되었다 $(p=0.113)$. 편도 및 아데노이드 절제술시 비갑개 후방 축소술을 동시 시행한 환 자군에서는 수술 전후 최소단면적은 $0.14 \pm 0.01,0.33 \pm 0.02$ $\mathrm{cm}^{2}$ 으로 측정되었다 $(p<0.05)$.

한편, 편도 및 아데노이드 절제술만 시행한 환자군에서는 수 술 전후 비강용적(nasal volume)은 $2.77 \pm 0.15,2.78 \pm 0.14 \mathrm{~cm}^{2}$ 로 측정되었다 $(p=0.071)$. 편도 및 아데노이드 절제술시 비갑개 후방 축소술을 동시 시행한 환자군에서는 수술 전후 비강용적 은 $2.90 \pm 0.13,3.80 \pm 0.11 \mathrm{~cm}^{2}$ 으로 측정되었다 $(p<0.05)$.

대조군에서는 검사상 유의미한 변화가 없었고, 실험군에 서는 최소단면적 및 비강용적에서 통계적으로 유의미한 개선

Table 1. Comparision of preoperative and postoperative Polysomnogram

\begin{tabular}{|c|c|c|c|}
\hline & Preoperative & Postoperative & $p$-value \\
\hline \multicolumn{4}{|l|}{$\mathrm{AHI}$} \\
\hline$T \& A$ & $7.85 \pm 1.90$ & $0.86 \pm 0.25$ & $<0.05^{*}$ \\
\hline T\&A with PTC & $8.60 \pm 4.41$ & $0.86 \pm 0.27$ & $<0.05^{*}$ \\
\hline p-value & & 0.966 & \\
\hline \multicolumn{4}{|c|}{ Oxygen saturationt (\%) } \\
\hline$T \& A$ & $88.6 \pm 1.6$ & $93.2 \pm 1.3$ & $<0.05^{*}$ \\
\hline T\&A with PTC & $89.0 \pm 1.6$ & $93.3 \pm 1.2$ & $<0.05^{*}$ \\
\hline p-value & & 0.904 & \\
\hline
\end{tabular}

$* p<0.05$ value was accepted as significant level. AHI: ApneaHypopnea Index, T\&A: Tonsillectomy and adenoidectomy, PTC: posterior turbinate coblation 
이 확인되었다(Table 2, Fig. 3).

\section{$\mathrm{KOSA}-18$ 을 통한 수술 전후 삶의 질 변화 비교}

두 집단 사이에서 수술 전 후 1 개월 시점에서 삶의 질 변 화를 평가하기 위해 KOSA-18을 이용하였다.

KOSA-18 총점수 $(\mathrm{N})$ 에 따라 삶의 질을 경도 $(\mathrm{mild}, \mathrm{N}<60)$, 중등도(moderate, $60 \leq \mathrm{N}<80$ ), 고도 (severe, $80 \leq \mathrm{N}$ )로 나누 어 평가하였다. 편도 및 아데노이드 절제술만을 시행한 대조 군에서 수술 전 경도군 0 명, 중등도군 3 명, 고도군이 22명으 로 평균점수 90.64 2 7.79점에서 수술 후 경도군 25명, 중등도 군 0 명, 고도군이 0 명으로 평균점수 $41.92 \pm 9.57$ 점으로 평가 되었다 $(p<0.05)$.

Table 2. Comparision of preoperative and postoperative of Acoustic rhinometry

\begin{tabular}{|c|c|c|c|}
\hline & Preoperative MCA & Postoperative MCA & $p$-value \\
\hline$T \& A$ & $0.14 \pm 0.01$ & $0.14 \pm 0.01$ & 0.113 \\
\hline T\&A with PTC & $0.14 \pm 0.01$ & $0.33 \pm 0.02$ & $<0.05^{*}$ \\
\hline \multirow[t]{2}{*}{$p$-value } & & $<0.05^{*}$ & \\
\hline & Preoperative NV $\left(\mathrm{cm}^{2}\right)$ & Postoperative NV $\left(\mathrm{cm}^{2}\right)$ & p-value \\
\hline$T \& A$ & $2.77 \pm 0.15$ & $2.78 \pm 0.14$ & 0.071 \\
\hline T\&A with PTC & $2.90 \pm 0.13$ & $3.80 \pm 0.11$ & $<0.05^{*}$ \\
\hline$p$-value & & $<0.05^{*}$ & \\
\hline
\end{tabular}

*p $<0.05$ value was accepted as significant level. T\&A: Tonsillectomy and adenoidectomy, PTC: posterior turbinate coblation, MCA: minimal cross section area, NV: nasal volume

A
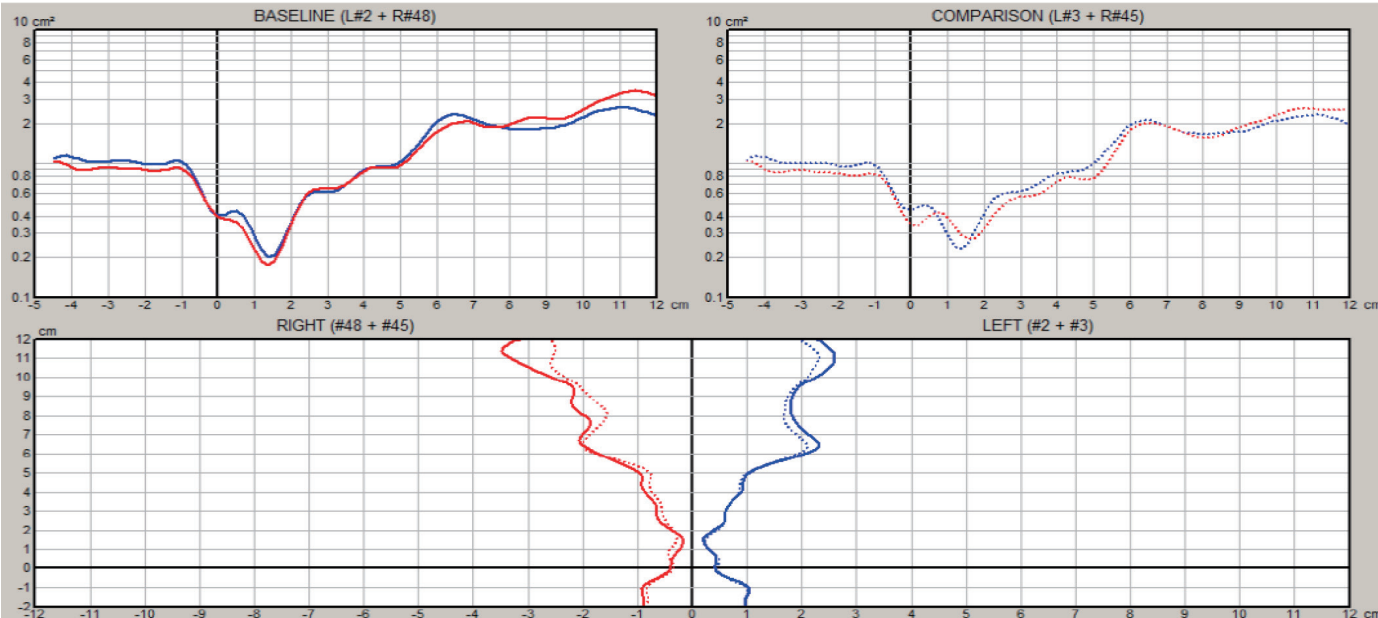

LEFT $(\# 2+\# 3)$
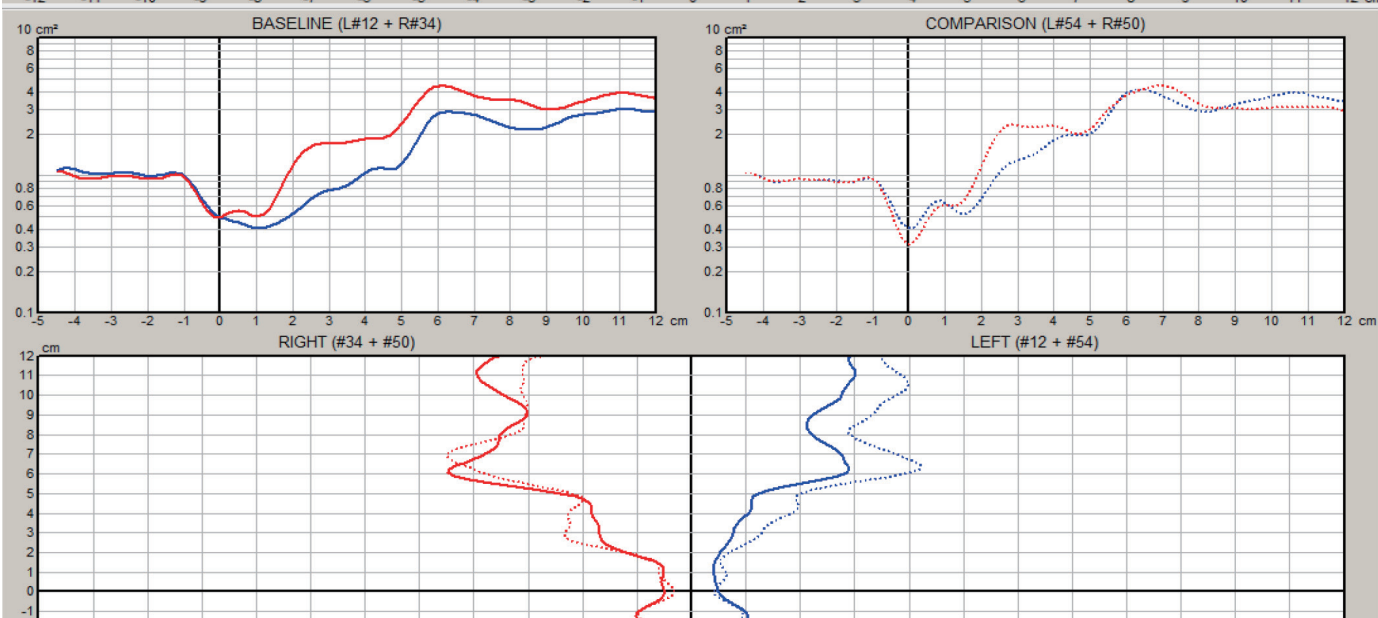

LEFT (\#12+\#54)

B

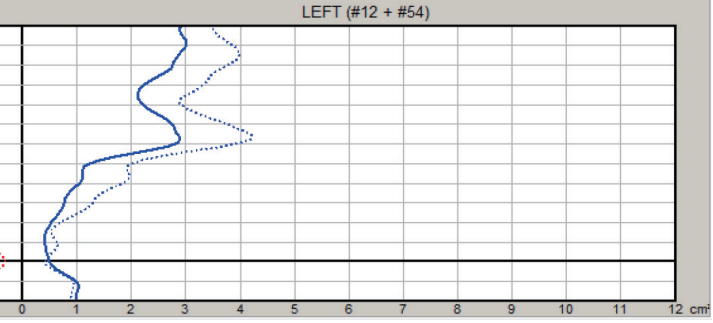

Fig. 3. Acoustic rhinometry. Postoperative MCA, NV were improved than preoperative those of the patient. Preoperative acoustic rhinometry (A). Postoperative acoustic rhinometry (B). MCA: minimal cross area, NV: nasal volume. 
Table 3. Comparision of preoperative and postoperative of KOSA-18

\begin{tabular}{lccc}
\hline & $\begin{array}{c}\text { Preoperative } \\
\text { KOSA-18 }\end{array}$ & $\begin{array}{c}\text { Postoperative } \\
\text { KOSA-18 }\end{array}$ & p-value \\
\hline T\&A & $90.64 \pm 7.79$ & $41.92 \pm 9.57$ & $<0.05^{*}$ \\
T\&A with PTC & $92.81 \pm 8.98$ & $34.76 \pm 7.39$ & $<0.05^{*}$ \\
p-value & & $0.008^{*}$ &
\end{tabular}

$* p<0.05$ value was accepted as significant level. T\&A: Tonsillectomy and adenoidectomy, PTC: posterior turbinate coblation, KOSA-18: Korean Obstructive Sleep Apnea-18 Survey

편도 및 아데노이드 절제술과 비갑개 후방 축소술을 동시 시행한 21 명의 실험군에서 수술 전 경도군 0 명, 중등도군 5 명, 고도군이 16명으로 평균점수 92.81 \pm 8.98 점에서 수술 후 경도군 21 명, 중등도군 0 명, 고도군이 0 명으로 평균점수 $34.76 \pm 7.39$ 점으로 평가 되었다 $(p<0.05)$.

두 군 모두에서 수술 전후 $\mathrm{KOSA}-18$ 평가의 뚜렷한 개선 이 확인되었다 $(p<0.05)$. 두 군 간 수술 후 상태 비교에서 KOSA-18 평가는 평균값의 차이가 있었으며 이는 통계적으 로도 유의하였다 $(p=0.008)$ (Table 3).

\section{고 찰}

수면호흡장애는 코골이, 상기도 저항 증후군, 폐쇄성수면 무호흡증을 포함하며, 공통적으로 기도가 좁아지는 것에 따 른 증상을 호소한다. ${ }^{11,12)}$ 그래서 여러 수술 방법을 통해 이러 한 증상을 개선하고자 많은 연구가 이루어져 왔다. 소아에서 수면호흡장애를 수술적으로 해결하기 위한 편도 및 아데노이 드 절제술을 계획한 환자들을 대상으로 비갑개 후방비대증 을 확인하고 이에 대해 축소술을 진행해 효과를 비교한 이번 연구를 통해 저자들은 편도 및 아데노이드 절제술을 통한 폐 쇄성수면무호흡증의 주된 개선을 다시 한 번 확인할 수 있었 다. 나아가 본 연구는 비갑개 후방비대증을 해소함으로서 술 후 잔존증상의 개선을 포함한 삶의 질 개선, 이를 통한 수술 에 대한 만족도 향상에 대해 확인하고자 하였다.

기존의 수면호흡장애와 비강폐쇄의 관련성에 대해 많은 연구가 있었고, Young 등 ${ }^{13)}$ 에 의한 연구결과에서 비강폐쇄 는 수면호흡장애의 위험인자라 하였고, Zwillich 등 ${ }^{14)}$ 은 비강 폐쇄 상황을 조성하여 수면 중 무호흡이 증가하게 됨을 확인 한 바 있으나 본 연구에서는 유사한 맥락에서 통계적으로 유 의미한 결과를 얻지 못하였다.

연구결과에서 비갑개 후방 coblation 후 비강 용적 및 평 균 단면적, 구강호흡 및 코골이 등 잔존증상 유무를 포함한 삶의 질에 있어서 뚜렷한 개선을 관찰할 수 있었으며 특히 KOSA-18 설문 결과에 있어서도 두 군간의 통계적으로 유의 한 차이를 확인할 수 있었다.
다만 술 후 수면다원검사 결과상 $\mathrm{AHI}$ 값 및 산소포화도 등에 있어서는 편도 및 아데노이드 절제술만을 시행한 군과 추가로 비갑개 후방축소술을 시행한 군 사이에서 통계적으 로 유의미한 차이를 확인하지는 못하였다. 이는 연구대상 환 아들은 편도 및 아데노이드 비대로 인한 폐쇄성수면무호흡 증이 기본적으로 있었기에 편도 및 아데노이드 절제술 이후 평가 가능한 $\mathrm{AHI}$ 값, 산소포화도 등 지표의 저명한 개선이 이루어지기 때문이라 생각된다. 이에 비해 비갑개 후방 축소 술을 통한 부분적 잔존 증상 개선의 효과는 상대적으로 작 은 수준이기에 통계적 차이를 보이지 않았다고 판단된다.

그러나 술 후 잔존 증상의 유무만을 평가 했을 때 비갑개 후방비대가 있는 환아들의 경우 편도 및 아데노이드 수술 시 비갑개 후방 축소술을 동시 진행한 경우에서 수술 후 더 나 은 삶의 질 개선이 있었으며 이는 곧 수술에 대한 만족도 개 선으로 이어지게 된다. 본 연구 결과를 토대로 판단하면 수 술 후 삶의 질 개선에 있어 비갑개 후방비대의 해소는 중요 한 요인으로 판단된다.

즉, 일련의 결과를 토대로 코골이 및 구강호흡 등 잔존증 상의 유무를 포함한 수술 후 삶의 질 개선과 만족도는 구강 내 편도 및 아데노이드에 의한 기계적 폐색은 물론 비갑개의 비대에 의한 비강 저항의 증가에 의해서도 상당히 영향을 받 고 있음을 알 수 있었다. 또한, 비강의 역할과 수면호흡질환 의 관계에 있어 일관된 결과가 없는 상태에서 수면 관련 수 술 후 잔존 증상 경감을 위해 비강에 대한 평가가 술 후 잔 여 증상을 경감시켜 만족도를 향상시킬 수 있다는 점도 확인 할 수 있었다. 특히 소아 폐쇄성수면무호흡증에 대한 편도 및 아데노이드 수술의 성공에 대한 평가에 있어 의료인에 비 해 환자 및 보호자는 잔존증상 및 삶의 질에 대한 부분에 더 민감할 수밖에 없다는 것을 고려할 때 중요한 의미를 갖는다 고 생각한다.

본 연구에서 편도 및 아데노이드 수술이 예정되어 있으며, 비내시경(sinus endoscopy)으로 반복 관찰 시에 비강의 $3 / 4$ 이상 공간을 차지하는 비갑개 후방 비대가 있는 상태를 저자 들이 새롭게 시도하는 비갑개 후방 축소술의 적응증으로 보 았다. 수술 시행에 있어 coblation을 통해 비강의 $50 \%$ 이내 로의 축소를 목표로 하여 절제범위를 정하였다. 연구를 통해 비갑개후방 축소술은 전신마취가 이미 예정된 환자에 대해 보완적 내지는 병행 치료의 개념에서 편도 및 아데노이드 수 술과 동시 진행하는 것을 고려 할 수 있다고 저자들은 판단 하였다.

또한, 본 연구를 통해서 출혈, 통증 및 비강 호흡시 불편감 등 예상하였던 합병증이 발생한 사례는 관찰되지 않았다. 더 많은 사례가 누적되고 이에 대한 장기적 연구관찰이 필요하 
겠지만 현재로서는 수술 범위, 시간 등의 간결성 및 술 후의 기대 효과가 부담해야 할 위험성에 비해 충분히 큰 것으로 판단된다.

한편, 일반적으로 소아에 있어 비강수술은 술 후 관리 및 처치의 문제로 특히 학령 전기 및 초기 아동에게 권장되지 않으며, 비중격 만곡증 등에서는 어느정도 코의 성장이 완성 되는 만 16 세 이후가 권장되나 비강호흡이 힘든 경우에는 적 극적으로 수술을 시행할 수 있다 ${ }^{15}$ 고 하였다. 본 저자들 역 시 전신마취가 주는 부담과 보완적 효과라는 점 등을 고려 할 때 수면호흡장애 해소를 위해 소아에서 비갑개 후방 축 소술만을 단독으로 시행하는 것은 일반적으로 권장하기 어 렵다고 보았다. 같은 맥락에서 환아들이 특별히 감당할 수술 후 처치나 어려움이 없는 간단한 수술이라 판단되기에 비갑 개 후방 비대증만을 연구대상으로 하였다.

한편, 편도 및 아데노이드 절제술과 동시 진행에 따른 포 괄수가제에 있어서의 문제, 비강 수술에 대한 보호자의 막 연한 불안, KOSA-18 평가가 보호자의 주관적 의견이 반영 되었다는 점, 환경 및 알레르기 등의 복합적 요인에 의한 비 강 상태의 변화 가능성 등은 본 연구의 한계로 생각된다. 또 한 후속연구를 통해 일반적 소아 비강수술의 치료 적응증 으로 비갑개 후방 축소술 시행이 갖는 안정성과 효과성 특 히 성인까지의 장기 추적 관찰에 대한 평가가 이루어지기를 기대한다.

\section{Acknowledgments}

None.

\section{Author Contribution}

Conceptualization: Jae Hoon Bae, Nam Guk Kim, Jang Su Lee. Data curation: Jae Hoon Bae, Nam Guk Kim. Formal analysis: Jae Hoon Bae. Investigation: Jae Hoon Bae, Nam Guk Kim. Methodology: Jae Hoon Bae, Nam Guk Kim, Jang Su Lee. Project administration: Jae Hoon Bae, Jang Su Lee. Resources: Jae Hoon Bae, Nam Guk Kim. Software: Jae Hoon Bae. Supervision: Jae Hoon Bae, Jang Su Lee. Validation: Jae Hoon Bae. Visualization: Jae Hoon Bae. Writing — original draft: Jae Hoon Bae, Nam Guk Kim, Jang Su Lee. Writing - review \& editing: Jae Hoon Bae, Nam Guk Kim, Jang Su Lee.

\section{ORCID}

Nam Guk Kim https://orcid.org/0000-0003-1326-5262

\section{REFERENCES}

1) Liu J, Liu X, Ji X, Wang Y, Zhou G, Chen X. Sleep disordered breathing symptoms and daytime sleepiness are associated with emotional problems and poor school performance in children. Psychiatry Res 2016;242:218-25.

2) Marcus CL. Sleep-disordered breathing in children. Am J Respir Crit Care Med 2001;164(1):16-30.

3) Greene MG, Carroll JL. Consequences of sleep-disordered breathing in childhood. Curr Opin Pulm Med 1997;3(6):456-63.

4) Tran KD, Nguyen CD, Weedon J, Goldstein NA. Child behavior and quality of life in pediatric obstructive sleep apnea. Arch Otolaryngol Head Neck Surg 2005;131(1):52-7.

5) Gysin C. Indications of pediatric tonsillectomy. ORL J Otorhinolaryngol Relat Spec 2013;75(3):193-202.

6) Marcus CL, Brooks LJ, Draper KA, Gozal D, Halbower AC, Jones $\mathrm{J}$, et al. Diagnosis and management of childhood obstructive sleep apnea syndrome. Pediatrics 2012;130(3):e714-55.

7) Masdon JL, Magnuson JS, Youngblood G. The effects of upper airway surgery for obstructive sleep apnea on nasal continuous positive airway pressure settings. Laryngoscope 2004;114(2):205-7.

8) Ellis PD, Harries ML, Ffowcs Williams JE, Shneerson JM. The relief of snoring by nasal surgery. Clin Otolaryngol Allied Sci 1992;17(6):525-7.

9) Choi JH, Lee SH, Lee HM, Lee JK, Kwon SY, Shin C, et al. Correlation between quality of life and personality, behavior problem in children with sleep disordered breathing. Korean J Otolaryngol-Head Neck Surg 2005;48(10):1235-41.

10) Franco RA Jr, Rosenfeld RM, Rao M. First place--resident clinical science award 1999. Quality of life for children with obstructive sleep apnea. Otolaryngol Head Neck Surg 2000;123(1 Pt 1):9-16.

11) Zwillich CW, Zimmerman J, Weil JV. Effects of nasal obstruction on sleep in normal men. Clin Res 1979;27:405.

12) Jang HU, Jung SS, Nam YM, Kim JS. The effect of septoturbinoplasty for quality of life in patients with sleep-disordered breathing. Korean J Otorhinolaryngol-Head Neck Surg 2011;54(4):257-64.

13) Young T, Finn L, Palta M. Chronic nasal congestion at night is a risk factor for snoring in a population-based cohort study. Arch Intern Med 2001;161(12):1514-9.

14) Zwillich CW, Pickett C, Hanson FN, Weil JV. Disturbed sleep and prolonged apnea during nasal obstruction in normal men. Am Rev Respir Dis 1981;124(2):158-60.

15) Lawrence R. Pediatric septoplasy: A review of the literature. Int J Pediatr Otorhinolaryngol 2012;76(8):1078-81. 